\title{
ZROZUMIEĆ SIEBIE SAMYCH I INNYCH. LUDZKI WYMIAR HISTORII W KSIĄŻCE ODWAGA I STRACH OLI HNATIUK
}

\author{
ANNA URSULENKO \\ Uniwersytet Wrocławski, Wrocław - Polska \\ annie.ursulenko@gmail.com
ЗРОЗУМІТИ САМИХ СЕБЕ ТА ІНШИХ. ЛЮДСЬКИЙ ВИМІР
ІСТОРІЇ В КНИЖЦІ ВІДВАГА І СТРАХ ОЛІ ГНАТЮК \\ АННА УРСУЛЕНКО \\ Вроцлавський університет, Вроцлав - Польща

\begin{abstract}
АНОТАЦІЯ. У статті розглянуто питання реконструкції психологічного ландшафту міста Львова часів Другої світової війни, що репрезентовано в книжці Biдвага i cmpax Олі Гнатюк, основу якої становить розповідь про долі львівської інтелігенції під час радянської та німецької окупації. Проаналізовано вибрані аспекти книжки, що утворюють своєрідне "case study" впливу феномена страху на життя окремих людей та спільнот в екстремальних умовах.
\end{abstract}

\section{TO UNDERSTAND ONESELF AND TO UNDERSTAND OTHERS. HUMAN DIMENSION OF HISTORY IN OLA HNATIUK'S \\ COURAGE AND FEAR}

\author{
ANNA URSULENKO \\ University of Wroclaw, Wroclaw - Poland
}

\begin{abstract}
ABSRACT. The article focuses on the analysis of the reconstruction of the psychological landscape of Lviv during World War II found in Ola Hnatiuk's Courage and Fear. The main theme of the book is the story of intelligentsia in Lviv under the Soviet and the Nazi occupations. The author has analyzed some aspects of the book that appear as a precise 'case study' of the impact of the phenomenon of fear on the lives of individuals and communities under extreme conditions.
\end{abstract}

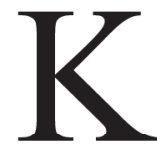

siążka Odwaga i strach (2015) Oli Hnatiuk to opowieść o losach lwowskiej inteligencji pod okupacją sowiecką oraz nazistowską. Książka, która gatunstarcza wiele przykładów opresji wojennych i dramatycznych kolizji z nimi związanych. Postawy ludzi w takich sytuacjach opisane przez Olę Hnatiuk z ogromną empatią pozwalają zrozumieć dramaty wyborów, które stały się udziałem przedstawicieli tego środowiska. Zastosowana przez autorkę ,zmiana perspektywy — z narracji narodowej na historię osobistą" sprawia, że leitmotivem opowieści stają się postawy poszczególnych osób wobec rozmaitych niebezpieczeństw wojny, a także wobec wyzwań natury psychicznej i etycznej. Autorka podkreśla, że stawiała przed sobą zadanie opisania relacji międzyludzkich w obliczu zagrożenia życia ${ }^{2}$. Znaczenie pro-

${ }^{1}$ O. Hnatiuk, Odwaga i strach, Wrocław-Wojnowice 2015, s. 11.

${ }^{2}$ O. Hnatiuk (w rozmowie z T. Leszkowiczem), Losy mieszkańców Lwowa były bardzo różne, [w:] Źródło elektroniczne: http://histmag.org/losy-mieszkancow-lwowa-byly-bardzo-rozne-12573 (21.03.2016) 
blematyki narodowościowej nie ulega dewaluacji, jednak zostaje ono zaprezentowane w ujęciu zgoła odmiennym od tego, do którego przyzwyczaiły nas prace wbudowane w historiograficzne matryce poszczególnych nacji. Ola Hnatiuk w następujący sposób tłumaczy zasadność, a wręcz konieczność zmiany perspektywy metodologicznej: „Dla każdej narracji narodowej, w której centrum znajduje się wspólnota etniczna, charakterystyczne jest zainteresowanie przede wszystkim losami «własnych" bohaterów. «Inni” mogą w niej odgrywać pewną ograniczoną rolę, pod warunkiem że wpisują się w jej kanon. Jeśli w tej narracji «swój” jest postrzegany jako ofiara, a «inny" jako wróg, to role są z góry wyznaczone, a narodowość bohaterów pozytywnych i negatywnych łatwa do przewidzenia. Na współpracę, pomoc i solidarność nie przewidziano tu miejsca"3. Zasadniczą intencją autorki była więc chęć pokazania, że różne losy jej bohaterów w czasie pożogi wojennej i po jej zakończeniu, uwarunkowane były nie tylko ich przynależnością narodową, ale także wyborami strategii przetrwania ${ }^{4}$. Autorka ukazuje historię okupowanego Lwowa na poziomie mikrohistorii, niemniej jednak z zachowaniem perspektywy makro, która pozwala zrozumieć szerszy kontekst opisywanych wypadków ${ }^{5}$.

$\mathrm{Na}$ ten kontekst składa się potworna tragedia wojny, etnicznych czystek, Holocaustu, a z perspektywy podjętego zagadnienia, te wszystkie procesy $\mathrm{i}$ wydarzenia, których odzwierciedlenie w książce pozwala mówić o niej również jako o swoistym "case study" wpływu fenomenu strachu na życie jednostek i zbiorowości w warunkach ekstremalnych. Jednym z najważniejszych świadectw tamtego czasu, na które wielokrotnie powołuje się Ola Hnatiuk, są notatki psychologiczne autorstwa Tadeusza Tomaszewskiego ${ }^{6}$. Zostały one wydane w 1996 roku pt. Lwów 1940 - 1944: pejzaż psychologiczny. W przedmowie napisanej do tego wydania psycholog zaznacza, że będzie w nich „mowa o mieszkańcach szczególnego miasta w bardzo szczególnej sytuacji”’ . Szczególność tej sytuacji polegała m. in. na tym, że mieszkańcom Lwowa przyszło stawić czoła nie tylko niebezpieczeństwom, które zazwyczaj się wiążą z wojną, lecz także zmierzyć się ze metodami rządzenia dwóch reżimów politycznych, które walczyły o przejęcie władzy nad terenami II Rzeczpospolitej. Kolosalna liczba ofiar tej wojny i bezprecedensowa skala zniszczeń, w tym spustoszeń psychicznych była uwarunkowana $\mathrm{m}$. in. tym, że głównymi graczami na arenie II wojny światowej stały się państwa totalitarne. Te państwa swoje ideologie stawiały ponad moralnością, co przesądzało o ich antyhumanitarnym charakterze. Uświadomienie skali i następstw manipulacji strachem, które towarzyszyło rozliczeniu tych reżimów stało się jednym z elementów właściwego osądu ich polityki oraz egzemplifikacją negatywnego wykorzystania mechanizmów psychospołecznych. Analizę przedstawionych w omawianym tekście poczynań nazistowskich Niemiec i Związku Radzieckiego w okupowanym Lwowie można zatem wpisać w krąg dociekań nad wykorzystaniem strachu jako narzędzia politycznego oraz instrumentu socjotechniki. Jednocześnie zastosowane przez autorkę środki psychologizacji opowieści — ukazanie jednostkowych życiorysów, udzielenie głosu świadectwom, uwypuklenie czynników wpływających na postawy jej bohaterów, a wraz z tym zaakcentowanie wagi in-

\footnotetext{
${ }^{3}$ Ibidem.

${ }^{4} \mathrm{O}$. Hnatiuk (w rozmowie z T. Leszkowiczem), Op. cit....

${ }^{5}$ Ibidem.

${ }^{6}$ Tadeusz Tomaszewski (1910-2000) - urodzil się we Lwowie, studiował na Uniwersytecie im. Jana Kazimierza, jeden z najwybitniejszych polskich psychologów, współtwórca polskiej psychologii powojennej. Z. W., Nestor polskiej psychologii, [w:] „Rzeczpospolita” 24.03.2000, Źródło elektroniczne: http://archiwum.rp.pl/artykul/269204-Nestor-polskiej-psychologii.html\#.V2HBPjUj6KQ (19.04.2016).

${ }^{7}$ T. Tom as zew ski, Lwów 1940-1944: pejzaż psychologiczny, Warszawa 1996, s. 7.
} 
dywidualnych wyborów — pobudzają do refleksji na temat znaczenia perspektywy humanistycznej dla narracji historycznej, a co za tym idzie także naszej zdolności dostrzegania ludzkiego wymiaru historii.

Jednym ze sposobów wykorzystania strachu w polityce jest terror. Termin ten powstał podczas Rewolucji Francuskiej, w okresie dyktatury jakobińskiej, która jako pierwsza praktykę instytucjonalizacji lęku, od wieków stosowaną przez tyranie, ujęła w teorię ${ }^{8}$. Przemoc w ten sposób, jak stwierdza Michela Marzano, została wyniesiona do rangi cnoty, stała się ideą politycznąa . Zarówno władze sowieckie, jak i nazistowskie na miarę gigantyczną stosowały ten środek dla spacyfikowania podbitej ludności i umocnienia swoich rządów na okupowanych terytoriach. Jak pisze Józef Pieter, terror jako metoda rządzenia, oparta o przemoc i szerzenie postrachu, ma na celu „posianie epidemii lęku przed więzieniami, torturami i straceniem"'10. Ola Hnatiuk nie poświęca dużej uwagi szczegółowym analizom nastrojów społecznych, często pozwalając faktom przemawiać samym za siebie. Autorka słusznie zapewne zakłada, że praca trafi do odbiorców wyposażonych w większy lub mniejszy bagaż wiedzy historycznej i wyobrażeń dotyczących grozy tamtej wojny. Z jednej strony mamy więc realizację głównego założenia autorki, które polegało na skoncentrowaniu narracji wokół doświadczeń jednostkowych, z drugiej — opisy reakcji poszczególnych ludzi na konkretne wydarzenia siłą rzeczy składają się na reprezentatywny obraz zachowań, charakterystycznych jeżeli nie dla wszystkich lwowian, to przynajmniej dla środowiska inteligencji albo pewnej jego części. Niemniej jednak opisy nastrojów społecznych pojawiają się w książce. Niekiedy autorka sięga po nie, by uzasadnić postawione tezy, a innym razem, by podkreślić psychologiczne skutki rządów, dla których wartość życia ludzkiego była znikoma. W pierwszym przypadku O. Hnatiuk trzyma się ściśle zasady, by jej stwierdzenia miały oparcie w tekstach, które mają charakter świadectw i zostały napisane w trakcie lub tuż po wojnie. Przykładowo w celu obalenia przekonania, że tylko Ukraińcy mogli się cieszyć z nadejścia niemieckiej armii autorka przywołuje następującą konstatację: „Wieści o zbrodni NKWD, które przed opuszczeniem miasta zdążyło wymordować tysiące więźniów, wywołują zgrozę i falę oburzenia" ${ }^{11}$. Tę opinię autorka opatruje cytatem, odsyłającym do notatek T. Tomaszewskiego oraz jego wnikliwych spostrzeżeń dotyczących przyczyn zadowolenia Polaków z wkroczenia Niemców. W drugim przypadku O. Hnatiuk odnosi się do zjawisk, które są przez nią postrzegane nie tylko jako znak czasu wojennego, ale także permanentna cecha systemu radzieckiego. W książce dwukrotnie pada stwierdzenie, że lęk przed wywózką, a także generalnie strach były nieodłącznym towarzyszem władzy sowieckiej ${ }^{12}$. Ilustracją tej opinii na przestrzeni książki stają się szczegółowe opisy niepewnej sytuacji niektórych z jej bohaterów. Chwiejność ich położenia wynikała $\mathrm{m}$. in. $\mathrm{z}$ tego, że nawet współpraca $\mathrm{z}$ Sowietami nie była indulgencją w oczach NKWD, zwłaszcza po powrocie władzy radzieckiej do Lwowa w 1944 roku. Ola Hnatiuk pisze: „Władze sowieckie nie zamierzały stosować taktyki podobnej do tej z jesieni 1939 roku: obłaskawiania ukraińskiej inteligencji. Przeciwnie, postanowiono wziąć ją za gardło. Ludność, która pozostała pod okupacją niemiecką, władze sowieckie a priori traktowały jako kolaborantów. Jeśli fakty temu przeczyły, wynajdywano inne preteksty do represji”"13. Owo wynajdywanie pretekstów do repre-

\footnotetext{
${ }^{8}$ M. Marzano, Oblicza lęku, przeł. Z. Chojn acka, Warszawa 2013, s. 92.

${ }^{9}$ Ibidem.

${ }^{10} \mathrm{~J}$. Pi eter, Walka ze strachem (strach i odwaga w życiu ludzkim), Katowice 1947, s. 67.

${ }^{11}$ O. Hnatiuk, Op. cit., s. 100.

${ }^{12}$ Ibidem, s. 28, 34.

${ }^{13}$ Ibidem, s. 485.
} 
sji jest również stałą cechą terroru. Jak pisze Józef Pieter terror wywołuje specyficzną formę strachu, który ma formę lęku imagicyjnego przed władzą grożącą represjami i śmiercią. Strach ten dodatkowo wzmacnia fakt, że ta władza regularnie wykonuje tego rodzaju groźby dla postrachu, nawet wobec osób niewinnych. Rządy terroru zatem dążą nie tylko do zapobiegania realnym $\mathrm{w}$ ich mniemaniu zagrożeniom, lecz przede wszystkim zmierzają do moralnego złamania rządzonych ${ }^{14}$. I jak pokazują liczne przykłady z dziejów świata środek ten rzadko zawodzi. Ola Hnatiuk tak pokazuje tę współzależność strachu i zdeprawowania: „Holocaustu we Lwowie, podobnie jak w innych miastach i miejscowościach, dokonali hitlerowcy. Jednakże bez udziału zastraszonego i zdemoralizowanego przez sowiecki terror społeczeństwa nazistom znacznie trudniej byłoby osiągnąć ten zbrodniczy cel"15.

W wachlarzu technik socjotechnicznych wykorzystywanych przez władze okupacyjne były też inne formy nacisku psychicznego. Jeden z podrozdziałów książki nosi tytuł „Donos - najkrótszy gatunek literacki”16. Jest w nim opisana historia pewnego donosu na wykładowcę Uniwersytetu Lwowskiego Mychajła Rudnyckiego sporządzonego przez pracownicę uczelni. Ponadto tytuł podrozdziału sugeruje, że pisanie donosów stało się powszechną praktyką zainstalowaną we Lwowie na wzór radziecki. Atmosfera donosicielstwa była niezbędna po to, żeby zapanowała ogólna podejrzliwość i nienawiść, a podziały powstające w takiej atmosferze miały z kolei uniemożliwić połączenie sił przeciwko władzy. Dominującymi emocjami miały się stać nienawiść, strach i rozpacz. Jednak by zrozumieć psychologiczny mechanizm, który najczęściej stał za decyzjami ludzi podejmujących się pisania donosów, należy odwołać się do rozróżnienia pojęć strachu i lęku stosowanego przez psychologów. Specjaliści pierwsze z pojęć definiują jako reakcję człowieka na widoczne i obiektywne zagrożenie, drugie zaś jako doznanie wywołane zagrożeniem ukrytym i subiektywnym. Lęk jako reakcją na uprzytomnienie możliwości niebezpieczeństwa ma więc charakter imaginacyjny $i$ antycypacyjny ${ }^{17}$. Warto jednak zaznaczyć, że między strachem wobec sytuacji naocznej a lękiem nie ma granic ostrych. „Z reguły jak pisze J. Pieter — w obliczu niebezpieczeństwa naocznego puszczamy w ruch naszą wyobraźnię, która wyolbrzymia rozmiary grozy"18. Działanie tego mechanizmu psychologicznego doskonale ilustrują zapiski T. Tomaszewskiego. Psycholog zaczął prowadzić zapiski po pół roku okupacji sowieckiej, kiedy, jak sam pisze, ,minął okres masowych aresztowań i wywózek”, a jednocześnie „,nowy porządek zaczynał się stabilizować"19. Wobec tej zmiany klimatu psycholog też odnotowuje zmianę uczuciowej dominanty krajobrazu psychologicznego miasta, pisząc, że obok słabnącego powoli strachu przed nową władzą, zaczął się krystalizować lęk m. in. o własną pozycję w nowym układzie. Podobnie pokazuje związek wyboru strategii przetrwania polegającej na donoszeniu a lękiem przed utratą pozycji zawodowej Ola Hnatiuk, opisując funkcjonowanie lwowskiego oddziału Związku Pisarzy Sowieckich w latach 1939 - 1941. Odbywało się ono, jak charakteryzuje autorka, „w atmosferze donosów, przepychanek oraz nieustannej walki o utrzymanie się na powierzchni"20.

\footnotetext{
${ }^{14} \mathrm{~J}$. Pieter, Op. cit., s. 67.

${ }^{15} \mathrm{O}$. Hnatiuk, Op. cit., s. 102.

${ }^{16} \mathrm{Ib}$ idem, s. 407.

${ }^{17}$ M. Wój towicz, Doświadczenie lęku egzystencjalnego jako sytuacja wyboru, Katowice 2005 ,

${ }^{18} \mathrm{~J}$. Pieter, $O p$. cit., s. 41-42.

${ }^{19}$ T. Tomaszewski, Op. cit., s. 9.

${ }^{20} \mathrm{O}$. Hnatiuk, Op. cit., s. 414.
} s. 27. 
W książce pojawiają się również inne przykłady świadczące o tym, że na udrękę czasów wojennych składały się nie tylko obawy przed represjami czy strach o własne życie, ale także rozmaite lęki. W przypadku wyższych warstw społeczności lwowskiej był to czasami lęk przed deklasacją. Przykładowo tuż przed wkroczeniem nazistów do Lwowa zamożna żydowska rodzina Lille $\mathrm{z}$ dwóch propozycji ukrycia ich, wybiera mniej bezpieczną, zostając w mieście, i odrzuca propozycję przeniesienia się do domu dawnej służącej, Ukrainki, mieszkającej na przedmieściach Lwowa. Ola Hnatiuk przypuszcza, że wśród innych prawdopodobnych motywów ich decyzji, jak np. nie zdawanie sobie spawy z powagi zagrożenia, była także podświadoma niechęć obniżenia prestiżowej pozycji ${ }^{21}$. Oczywiście wkroczenie do Lwowa Niemców oznaczało drastyczną zmianę sytuacji ludności żydowskiej. Jednak ta zmiana miała też zasadniczy wpływ na samopoczucie Polaków, na położeniu których skupia głównie swoją uwagę T. Tomaszewski. Wcześniejsze lęki, jak pisze psycholog, ustępują miejsca jednej dominującej emocji - strachowi o przetrwanie ${ }^{22}$.

Zarówno jedna, jak i druga władza okupacyjna stosowała zasadę "dziel i rządź". Owo "dzielenie" oprócz decyzji administracyjnych (np. sowietyzacji Lwowa, początkowo przyodzianej w szaty ukrainizacji czy nazistowski podział ludności na kategorie, który uprzywilejowywał Ukraińców w stosunku do Polaków) w dużej mierze było wdrażane za pomocą agitacji i propagandy. Propaganda była dla tych reżimów totalitarnych podstawowym narzędziem wywierania wpływu nie tylko na własne społeczeństwa, ale i na ludność okupowanych państw. Jedną z podstawowych technik, z której korzysta propaganda do przekazywania i utrwalania idei jest argumentum ad metum (nazywana również argumentum in terrorem), polegająca na „wzmacnianiu przekazywanej idei poprzez odwołanie się do strachu i uprzedzen'"23. Podstawowym instrumentem staje się więc operowanie argumentami wzbudzającymi lęk przed Innym, który ma być odbierany jako siła bezapelacyjnie obca i wroga. Wielokulturowy Lwów doświadczył tej socjotechnicznej ofensywy w pełni. Ówczesne poczynania propagandy radzieckiej pokazują, iż internacjonalizm ideologii komunistycznej miał w 7SSR charakter fasadowy, ponieważ jedną z podstawowych praktyk było utrwalanie i pogłębianie podziałów narodowych. Działania Sowietów miały na celu zbudowanie atmosfery podejrzeń i nienawiści wszystkich wobec wszystkich - strach miał wzmacniać stereotypy i budować mury ${ }^{24}$. Ola Hnatiuk zwraca uwagę, że szczególną wagę władze radzieckie przywiązywały do rozgrywania konfliktu polsko-ukraińskiego: „Potężna machina propagandy sowieckiej z antyburżuazyjnej czy antyfaszystowskiej przestroiła się na stricte antypolską, pozostawiając jednak dotychczasowe metody i obrazy"25. Natomiast władze nazistowskie szczególnie aktywnie wykorzystywały wypróbowane w Niemczech metody i obrazy agitacji antysemickiej. Hitler, jak podkreśla Tymothy Snyder, nie zrezygnował $z$ retoryki międzynarodowego spisku żydowskiego przeciwko Niemcom nawet, gdy „jego armie podbiły znaczną część Europy, a jego instytucje mordowały miliony Ży-

\footnotetext{
${ }^{21}$ Ibidem, s. 103.

${ }^{22}$ T. Tomaszewski, Op. cit., s. 10.

${ }^{23}$ A. S te fańc zyk, Psychologia wywierania wpływu i psychomanipulacji, Warszawa, 2008, s. 164.

${ }^{24}$ Historyk Grzegorz Motyka tak pokazuje ten mechanizm napędzania konfliktu polsko-ukraiń-
} skiego: „Z jednej strony w Galicji budowano tożsamość ukraińską w kontrze do Polaków, z drugiej o kultywowanie tego obrazu dbała władza sowiecka". G. Motyka (w rozmowie z R. Mazurkiem), Potrafimy wypić za Chmielnickiego, [w:] „Rzeczpospolita” 01.02.2014, Zródło elektroniczne: http://archiwum. rp.pl/artykul/1231186-Potrafimy--wypic-za-Chmielnickiego-.html?_=Rzeczpospolita-1231186?_=18\#. V2G7ZjUj6KQ (16.02.2016).

${ }^{25} \mathrm{O}$. Hnatiuk, Op. cit., s. 414. 
dów"26. Jednym ze sposobów pobudzenia destrukcyjnej siły odruchu ksenofobicznego człowieka jest sięgnięcie po argument zagrożenia chorobą zakaźną. Dlatego m.in. we Lwowie oprócz wszelkich innych rzekomych win, jak przypomina Ola Hnatiuk, propaganda niemiecka przypisywała Żydom szerzenie epidemii tyfusu ${ }^{27}$. W ten sposób w mieście próbowano wzbudzić strach przed grupą narodową, która przecież nie mogła stanowić dla miejscowej ludności żadnego realnego zagrożenia. Jednak metologom ${ }^{28}$ doskonale jest znany fakt, iż sytuacje kryzysowe szczególnie sprzyjają wprowadzeniu klimatu panicznego lęku, który z kolei, jak pisze Michela Marzano, pozwala na sięgnięcie po dyskusyjne metody, aby się pozbyć "przeszkadzających", czyli "innych", "dewiantów", "nienormalnych"29.

Tak wyglądają wybrane przykłady implantowania fenomenu strachu za pomocą różnych metod rządzenia i środków socjotechniki w przestrzeń społeczną okupowanego Lwowa. Zasadnym będzie zatem pytanie, jakie odzwierciedlenie znalazły te zjawiska w życiu poszczególnych ludzi. Jak już bowiem wspomniano autorka skupiła się na mikrohistoriach, czyli przedstawieniu indywidulanych historii swoich bohaterów. I tu czytelnika może czekać pewnego rodzaju zaskoczenie. Przy charakterystyce osób czy dociekaniu ich motywacji autorka unika sięgania po argumenty w rodzaju "kierował nim strach". Na jednej z prezentacji książki Ola Hnatiuk podkreśliła, że czuła się upoważniona do mówienia o strachu tylko w przypadkach, gdy pisała o swojej rodzinie lub gdy była możliwość udzielenia głosu samym bohaterom ${ }^{30}$. $\mathrm{Z}$ jednej strony wynika to $\mathrm{z}$ założeń warsztatowych autorki, żeby przedstawiać wyłącznie twarde fakty zaczerpnięte $z$ dokumentów epoki i dodatkowo zweryfikowane poprzez skonfrontowanie różnych źródeł. $Z$ drugiej - można przypuszczać, że chodzi również o podejście, które pozwalamy sobie nazwać założeniem etycznym autorki. Wiąże się to $\mathrm{z}$ tym, że mówienie o strachu nieodmiennie pociąga za sobą temat odwagi, a to z kolei, jak podkreśla hiszpański psycholog i filozof José Antonio Marina, przenosi nas z obszaru psychologii do sfery etyki. Strach to jest bowiem emocja, a odwaga - sposób zachowania się człowieka. Hiszpański myśliciel, autor dzieła pt. Anatomía del miedo: un tratado sohre la valentía [Anatomia strachu. Traktat o męstwie] pokazuje, że dialektyka strachu i nadziei, strachu i odwagi została zauważona już przez antycznych filozofów. I chociaż od tamtej pory model męstwa ulegał czasami istotnym modyfikacjom, to przegląd licznych refleksji na ten temat, od starożytności do czasów dzisiejszych, świadczy o tym, że nie sposób mówić o odwadze człowieka, pomijając temat strachu. Myśl, iż u podstaw odwagi stoi pokonanie strachu, pozostaje niepodważalna ${ }^{31}$. Podobny sposób rozumowania jest również ideą przewodnią książki Oli Hnatiuk, o czym świadczy chociażby jej tytuł. Tym nie mniej Ola Hnatiuk, jak można przypuszczać, jest świadoma pułapek strategii zestawiania tych zjawisk. Niebezpieczeństwo polega na tym, że operując choć i skorelowanymi, ale jednak w powszechnym odbiorze antonimicznymi pojęciami, można wywo-

${ }^{26}$ T. Snyder, Skrwawione ziemie. Europa między Hitlerem a Stalinem, thum. B. Pietrzyk, Warszawa 2015, s. 85.

${ }^{27} \mathrm{O}$. Hnatiuk, Op. cit., s. 58.

${ }^{28}$ Terminy metologia i metolog (od łac. metus - stach) zaproponował José Antonio Marina dla określenia nauki i specjalistów zajmujących się zjawiskiem strachu. X. А. Марина, Анатомия страха. Трактат о храбрости, CORPUS, 2010, [w:] Źródło elektroniczne: http://royallib.com/book/ marina_hose_antonio/anatomiya_straha_traktat_o_hrabrosti.html (09.03.2016).

${ }^{29}$ M. Marzano, Op. cit., s. 17.

${ }^{30}$ Prezentacja odbyła się w dniu 30 kwietnia 2016 r. we Wrocławiu (Synagoga Pod Białym Bocianem).

${ }^{31}$ X. А. Марина, Op. cit., [w:] Źródło elektroniczne: http://royallib.com/book/marina_hose_ antonio/anatomiya_straha_traktat_o_hrabrosti.html (14.04.2016). 
łać u odbiorcy wrażenie, że ma on do czynienia z czarno-białą opowieścią o tchórzostwie i męstwie. Zapewne w celu uniknięcia takiego nieporozumienia, autorka podczas prezentacji powtarza, iż w jej książce, oprócz tytułu, wyraz odwaga pojawia się prawdopodobnie jeden raz ${ }^{32}$. W rzeczywistości w tekście głównym ten wyraz występuje dziewięć razy. Nie jest to jednak rzecz zasadnicza dla tekstu, który liczy ponad pięćset stron. O wiele istotniejszą kwestią, naszym zdaniem, jest to, że książka może być doskonałą ilustracją myśli, że podobnie jak strach, tak i odwaga ma wiele oblicz. Rezygnując więc z pojęć generalnych, autorka osiąga dwa istotne efekty. Po pierwsze, prezentuje godną naśladownictwa postawę etyczną, wykazując się ogromnym taktem w mówieniu o wyborach ludzi, dla których przezwyciężenie strachu na rzecz odwagi oznaczało wybór pomiędzy minimalnym bezpieczeństwem a życiem w ciągłym zagrożeniu. Nie przypadkowo w jednym $z$ rozdziałów zostaje przywołana postać Hamleta, w interpretacji autorki, symbol tragicznego wyboru pomiędzy życiem a śmiercią ${ }^{33}$. Po drugie, obrana strategia pozwala autorce pokazać złożoność motywacji i wielość wariantów zachowania, które nazwalibyśmy odważnym lub bohaterskim, zważając na okoliczności tamtego czasu. A zatem odwaga w tej opowieści niejedno ma imię.

Jest to przede wszystkim postawa wobec doświadczenia granicznego, czyli masowej zagłady Żydów. Babcia autorki przechowywała w swoim mieszkaniu przez czas wojny sześć osób, a także wraz z ukraińską malarką Jarosławą Muzyką nosiła jedzenie i medykamenty do lwowskiego getta. Nie trzeba przypominać, że za to wszystko w warunkach okupacji niemieckiej groziła śmierć. Odwaga jest również potrzebna, by w czasie ogromnych napięć międzyetnicznych wznieść się ponad podziały narodowe i okazać solidarność w potrzebie. Przykładem może służyć postać znanego ukraińskiego działacza Kyryła Studynskiego, który będąc sowieckim deputowanym, dokładał wszelkich starań, by pomagać więźniom, zesłańcom czy duchowieństwu. Nie czynił on różnicy ze względu na narodowość potrzebującej osoby. Został zlikwidowany przez NKWD w 1941 r. Odwagą należy także wykazać się, by nie bać się narazić sowieckiemu decydentowi. Tak jak to zrobił Mychajło Rudnycki, występując podczas jednego z zebrań $\mathrm{z}$ wnioskiem o zreasumowanie wystąpień $\mathrm{w}$ języku polskim ze względu na polskich i żydowskich pisarzy. Literat zrobił to pomimo sprzeciwu radzieckiego przewodniczącego. Nie ulega wątpliwości, że każdy akt cywilnej odwagi oznaczał wtedy trafienie pod czujne oko NKWD. Z kolei odwaga dla wysłanników radzieckiej władzy — ta perspektywa też jest w książce obecna i stanowi istotne novum w mówieniu o losach Lwowa po 1939 r. — oznaczała wyjście poza rolę ślepego wykonawcy poleceń. Tak jak to czynił pierwszy radziecki rektor Uniwersytetu Lwowskiego Mychajło Marczenko, próbując rozszerzyć granice dozwolonego na polu historii Ukrainy w nauce radzieckiej.

I wreszcie można powiedzieć, że omawianą książkę również należy uznać za rezultat odwagi, a ściślej mówiąc - odwagi poznawczej. Zniuansowana opowieść o relacjach ukraińskiej, polskiej i żydowskiej wspólnoty Lwowa okresu wojny jest bowiem odległa od tego, co znamy z licznych relacji świadków i innego typu leopolianów. Jak pisze Timothy Snyder, polecając omawianą publikację: „To przekonujące studium pluralizmu, znajdującego odzwierciedlenie w konkretnych uczynkach, w konkretnym mieście, wśród przyjaciół, w rodzinie czy choćby własnym umyśle"34. Ola Hnatiuk zdaje sobie sprawę, że jej książka może wywołać rozmaite zarzuty

${ }^{32}$ Wspomniane prezentacje miały miejsce we Wrocławiu: 15 grudnia 2015 r. w Zakładzie Narodowym im. Ossolińskich oraz 30 kwietnia 2016 r. w Synagodze Pod Białym Bocianem.

${ }^{33}$ O. IInatiuk, Op. cit., s. 385.

${ }^{34}$ T. Snyder, Blurb na tylnej stronie okładki książki. 
ze strony zwolenników narracji, koncentrujących się na martyrologii własnej wspólnoty i utrwalonych w narodowych matrycach historiograficznych ${ }^{35}$. Przede wszystkim dlatego, że jej nowy sposób odczytania dziejów wojennego Lwowa zmienia kompletnie obraz historii, w którym nie ma miejsca na przejawy ponadnarodowej solidarności i wzajemnego wsparcia ${ }^{36}$. Tym niemniej, podejmuje ona wyzwanie stworzenia polifonicznej opowieści, idącej na przekór zarówno ciasnym stereotypom historycznym, jak i ograniczającym narracjom narodowym. Dramat wojny rozpisany na biografie konkretnych osób pozwala czytelnikowi sięgnąć do zasobów własnej wyobraźni empatycznej i odczuć grozę ówczesnej sytuacji, a wraz z tym docenić siłę ich odwagi. Jednostkowe ujęcie losów bohaterów, przedstawicieli różnych narodowości, akcentuje uniwersalność ludzkich doświadczeń oraz zachęca do mentalnego przekroczenia granic uprzedzeń i urazów narodowych.

${ }^{35} \mathrm{O}$. Hnatiuk (w rozmowie z I. Mrzygłód), Chciałam być jak najbliżej jednostkowego doświadczenia, [w:] Źródło elektroniczne: http://kulturaliberalna.pl/2015/12/01/wywiad-ola-hnatiuk-izamrzyglod-odwaga-i-strach/ (20.02.2016).

${ }^{36} \mathrm{O}$. Hnatiuk, Op. cit., s. 11. 